Article

\title{
Ocimum campechianum Mill. from Amazonian Ecuador: Chemical Composition and Biological Activities of Extracts and Their Main Constituents (Eugenol and Rosmarinic Acid)
}

\author{
Massimo Tacchini ${ }^{1} \oplus$, Monica Paulina Echeverria Guevara ${ }^{2} \mathbb{D}$, Alessandro Grandini ${ }^{1}$, Immacolata Maresca ${ }^{1}$, \\ Matteo Radice ${ }^{2}$ (D) Letizia Angiolella ${ }^{3}$ and Alessandra Guerrini ${ }^{1, *(D)}$ \\ 1 Pharmaceutical Biology Laboratory, Technopole Terra\&Acqua Tech (Research Unit 7), Department of Life \\ Sciences and Biotechnology, University of Ferrara, P.le Luciano Chiappini 3, Malborghetto di Boara, \\ 44123 Ferrara, Italy; massimo.tacchini@unife.it (M.T.); alessandro.grandini@unife.it (A.G.); mci@unife.it (I.M.) \\ 2 Department of Earth Science, Universidad Estatal Amazónica, Puyo 160106, Ecuador; \\ mecheverria@uea.edu.ec (M.P.E.G.); mradice@uea.edu.ec (M.R.) \\ 3 Department of Public Health and Infectious Diseases, Sapienza University of Rome, P.le Aldo Moro 5, \\ 00165 Rome, Italy; letizia.angiolella@uniroma.it \\ * Correspondence: alessanda.guerrini@unife.it; Tel.: +39-053-229-3774
}

Citation: Tacchini, M.; Echeverria Guevara, M.P.; Grandini, A.; Maresca I.; Radice, M.; Angiolella, L.; Guerrini, A. Ocimum campechianum Mill. from Amazonian Ecuador: Chemical Composition and Biological Activities of Extracts and Their Main Constituents (Eugenol and Rosmarinic Acid). Molecules 2021, 26 84. https://dx.doi.org/10.3390/ molecules26010084

Academic Editor: Luisella Verotta Received: 7 October 2020

Accepted: 23 December 2020

Published: 27 December 2020

Publisher's Note: MDPI stays neutral with regard to jurisdictional claims in published maps and institutional affiliations.

Copyright: (C) 2020 by the authors. Licensee MDPI, Basel, Switzerland. This article is an open access article distributed under the terms and conditions of the Creative Commons Attribution (CC BY) license (https: / / creativecommons.org/ licenses/by/4.0/).

\begin{abstract}
The essential oil (EO), the methanolic (MeOH), and the 70\% ethanolic $(70 \% \mathrm{EtOH})$ extracts obtained from the aerial parts of Ocimum campechianum Mill. (Ecuador) were chemically characterized through gas-chromatography coupled to mass spectrometry detector (GC-MS), high-performance liquid chromatography coupled to diode array-mass spectrometry detectors (HPLC-DAD-MS) and studied for their in vitro biological activity. The radical scavenger activity, performed by spectrophotometric 1,1-diphenyl-2-picrylhydrazyl (DPPH) and 2,2'-azino-bis(3-ethylbenzothiazoline-6-sulfonic acid) (ABTS) assays, highlighted significant $\mathrm{IC}_{50}$ values for the $\mathrm{EO}$, extracts and their main constituents (eugenol and rosmarinic acid). EO (and eugenol) showed noteworthy activity against Pseudomonas syringae pv. syringae and a moderate effect against clinical Candida strains, with possible synergism in association to fluconazole against the latter microorganisms. The extracts and pure molecules exhibited weak cytotoxic activity against the HaCat cell line and no mutagenicity against Salmonella typhimurium TA98 and TA100 strains, giving indication of safety. Instead, EO showed a weak activity against adenocarcinomic human alveolar basal epithelial cells (A549). The above-mentioned evidence leads us to suggest a potential use of the crude drug, extracts, and EO in cosmetic formulation and food supplements as antioxidant agents. In addition, EO may also have a possible application in plant protection and anti-Candida formulations.
\end{abstract}

Keywords: Ocimum campechianum; antioxidant activity; plant protection; cytotoxicity; synergistic activity

\section{Introduction}

Ecuador is well known for its biodiversity and is considered among the 17 megadiverse countries, counting about $10 \%$ of all plant species in the world and having the third highest density of endemic ones: about 4000 out of a total of 20,000 [1,2]. The aromatic plants of Amazonian Ecuador represent an appropriate renewable source for the production of essential oils and flavors, and an interesting economic alternative to sustainable development, with the perspective of generating wealth for this region. Numerous studies have been conducted in the Amazonian area of Ecuador, particularly describing the chemodiversity of essential oils as well as other natural bioactive molecules that may find application in food, beverages, cosmetics, pharmaceuticals, and pesticides [3-6]. However, about 50\% of all the scientific publications on the botanical native species are related to only eight families (Arecaceae, Poaceae, Asteraceae, Fabaceae, Cucurbitaceae, Solanaceae, Orchidaceae, and Euphorbiaceae), while the remaining 246 are scarcely studied, with few or no publications on either phytochemistry or ethnopharmacology. As a result, many species are still little 
explored [7]. To complete this scenario, it should be noted that the overharvesting of crude drugs in the wild for the formulations of pharmaceutical and herbal products has often led to the depletion of valuable natural resources, and any program that attempts to promote their use must incorporate strategies for the sustainable sourcing of raw materials. The relationship between tropical biodiversity, conservation, and human health is complex and should not be oversimplified. The most effective way in which health and conservation can be combined to serve the needs of local and international communities is by incorporating this complexity into a package of complementary activities including the development of natural products $[8,9]$. Within this context, the cooperation among University of Ferrara (Italy), Amazonian State University (Ecuador), and other Ecuadorian Universities was born to perform, over the years from 1996 to now, various research activities on endemic species of the Amazon region, studying in particular essential oils of well-known genera of traditional medicine, such as Piper, Ocotea, Citrus, and Croton, and almost unexplored ones such as Hedyosmum and Myrcia [1,4,6,10-14], promoting the training of local researchers in Italy, through a $\mathrm{PhD}$ program, collaborating in the development of sustainable Ecuadorian supply chains.

In this research work we have dealt with Ocimum campechianum Mill. (synonym Ocimum micranthum Willd.), belonging to Lamiaceae family, an interesting native species of the South and Central American tropics, known as "Albahaca de campo" or "Albahaca silvestre" and widely used by indigenous population both for culinary and medicinal purposes. This species has already been studied in previous research works especially for leaf and aerial parts EO which has been shown to have antifungal, insect repellent and analgesic activities [10,15-18]. Only recently Ruiz-Vargas et al. (2020) [19] reported the isolation, identification, and biological evaluation of some secondary metabolites present in the leaf infusion of $O$. campechianum.

The aim of our research was the chemical characterization of the EO and, for the first time, of the hydroalcoholic extracts of aerial parts, combined with the evaluation of their biological activity and that of their main constituents, providing a more exhaustive approach for studying the health potential of this species. In fact, the combination of critically assessed compositional data and biological effects may increase the scientific soundness of research [20]. In addition, we tested in vitro preliminary phytopathogenic activity with the precise aim of identifying promising extracts for further investigations with respect to the phytoiatric application, or for the sustainable defense of the crops.

\section{Results and Discussion}

\subsection{Chemical Characterization}

The EO content and composition were similar to our previous published results [10,18]. Briefly, the extraction yield (EO content) was $0.71 \pm 0.01 \%$ and thirty-one compounds were identified corresponding to $97.1 \%$ of the total. The most abundant component (Table 1) was the monoterpene eugenol ( $43.6 \%)$, followed by 1,8 -cineole $(4.4 \%)$; among the sesquiterpenes, we detected $\beta$-caryophyllene (10.8\%), $\beta$-elemene $(8.1 \%), \delta$-elemene $(4.2 \%)$, and bicyclogermacrene $(2.9 \%)$, which is consistent with results reported by other authors $[10,18]$. 
Table 1. Essential oil composition of O. campechianum.

\begin{tabular}{|c|c|c|c|c|}
\hline No. & Component $^{1}$ & Area $\%{ }^{2}$ & $A I \exp ^{3}$ & AI lit ${ }^{4}$ \\
\hline 1 & $\alpha$-pinene & 0.3 & 929 & 932 \\
\hline 2 & camphene & 0.1 & 944 & 946 \\
\hline 3 & sabinene & 0.8 & 967 & 969 \\
\hline 4 & $\beta$-pinene & 1.2 & 973 & 974 \\
\hline 5 & myrcene & 2.3 & 987 & 988 \\
\hline 6 & 1,8-cineole & 4.4 & 1028 & 1026 \\
\hline 7 & cis- $\beta$-ocimene & 1.3 & 1030 & 1032 \\
\hline 8 & trans-ocimene & 0.4 & 1046 & 1044 \\
\hline 9 & linalool & 1.6 & 1101 & 1095 \\
\hline 11 & allo-ocimene & 1.7 & 1126 & 1128 \\
\hline 12 & $\begin{array}{c}\text { mentha-1,5 } \\
\text { dien-8 ol }\end{array}$ & 0.3 & 1170 & 1166 \\
\hline 13 & $\alpha$-terpineol & 0.4 & 1189 & 1186 \\
\hline 14 & neral & 0.1 & 1238 & 1235 \\
\hline 15 & $\delta$-elemene & 4.2 & 1338 & 1335 \\
\hline 16 & eugenol & 43.6 & 1359 & 1356 \\
\hline 17 & $\alpha$-copaene & 0.5 & 137 & 1374 \\
\hline 19 & $\beta$-elemene & 8.1 & 1388 & 1389 \\
\hline 20 & $\begin{array}{c}\beta- \\
\text { caryophyllene }\end{array}$ & 10.8 & 1410 & 1416 \\
\hline 21 & $\gamma$-elemene & 0.3 & 1427 & 1434 \\
\hline 22 & $\begin{array}{c}\text { trans- } \alpha- \\
\text { bergamotene }\end{array}$ & 0.6 & 1431 & 1435 \\
\hline 23 & $\alpha$-caryophyllene & 1.9 & 1451 & 1452 \\
\hline 24 & $\begin{array}{c}\text { allo- } \\
\text { aromadendrene }\end{array}$ & 1.4 & 1455 & 1458 \\
\hline 25 & germacrene D & 0.4 & 1477 & 1484 \\
\hline 26 & $\beta$-selinene & 1.1 & 1484 & 1489 \\
\hline 27 & viridiflorene & 0.4 & 1489 & 1496 \\
\hline 27 & bicyclogermacrene & 2.9 & 1490 & 1500 \\
\hline 28 & germacrene A & 1.0 & 1500 & 1508 \\
\hline 29 & germacrene B & 1.6 & 1556 & 1559 \\
\hline 30 & spathulenol & 1.5 & 1576 & 1577 \\
\hline \multirow[t]{2}{*}{31} & $\begin{array}{l}\text { caryophyllene } \\
\text { oxide }\end{array}$ & 1.9 & 1581 & 1582 \\
\hline & Total identified & 97.1 & & \\
\hline
\end{tabular}

${ }^{1}$ Components are listed in order of elution and their nomenclature is in accordance of the NIST (National Institute of Standards and Technology) library. ${ }^{2}$ Relative peak areas, calculated by GC-FID.

${ }^{3}$ AI exp: linear retention indices calculated on Varian VF-5 ms column. ${ }^{4}$ AI lit: linear retention indices [21]. The main compounds were in bold

Other chemotypes present in literature are characterized by methyleugenol (62.0\%), recognized in the specimens collected from Pará State (Brazil) and Chocò (Colombia); by 1,8-cineole (61.8\%) and sabinene (16.4\%), identified in two specimens collected in Piauí State (Brazil); and by $\beta$-caryophyllene (78.6\%) and 1,8-cineole (13.0\%), which are the main compounds of the Maranhão (Brazil) and Germany O. campechianum EO [15-17,22].

Table 2 showed the composition of alcoholic extracts, chemically characterized for the first time in this research. The mass fragmentations of molecules were in according to previous literature $[23,24]$. The methanolic and hydro-alcoholic extracts with a yield of $5.3 \pm 0.2 \%$ and $19.2 \pm 0.2 \%$, respectively, showed a similar fingerprinting where rosmarinic acid was the main compound, followed by rutin, caftaric and chlorogenic acids as minor components. 
Table 2. Main constituents identified in extracts of O. campechianum by HPLC-DAD, highperformance liquid chromatography/electrospray ionization mass spectrometry (HPLC-ESI-MS), and $\mathrm{MS}^{2}$.

\begin{tabular}{|c|c|c|c|c|c|}
\hline$\underset{\mathrm{a}}{\text { Compound }}$ & $\begin{array}{c}\text { 70\% EtOH Extract } \\
\text { mg/g d.e. (mg/g } \\
\text { drug) }\end{array}$ & $\begin{array}{l}\text { MeOH Extract } \\
\text { mg/g d.e. (mg/g } \\
\text { Drug) }^{b}\end{array}$ & $\begin{array}{c}\mathbf{U V} \\
\kappa_{\max }(\mathrm{nm})\end{array}$ & $\begin{array}{c}{[\mathbf{M}-\mathbf{H}]^{-}} \\
\quad(m / z)\end{array}$ & $\begin{array}{l}\operatorname{MS}^{2}(m / z) \\
\text { Base Peak }\end{array}$ \\
\hline Caftaric acid & $\begin{array}{c}0.35 \pm 0.01(0.07 \pm \\
0.00)\end{array}$ & $\begin{aligned} 0.57 & \pm 0.01(0.03 \\
& \pm 0.00)\end{aligned}$ & 327 & 311 & 149 \\
\hline $\begin{array}{l}\text { Chlorogenic } \\
\text { acid }\end{array}$ & $\begin{array}{c}0.27 \pm 0.01(0.05 \pm \\
0.00)\end{array}$ & $\begin{array}{c}0.05 \pm 0.01 \\
(0.003 \pm 0.000)\end{array}$ & 327 & 353 & 191 \\
\hline Rutin & $\begin{array}{c}0.63 \pm 0.01(0.12 \pm \\
0.01)\end{array}$ & $\begin{aligned} 0.56 & \pm 0.01(0.02 \\
& \pm 0.00)\end{aligned}$ & 255,355 & 609 & 301 \\
\hline $\begin{array}{l}\text { Rosmarinic } \\
\text { acid }\end{array}$ & $\begin{array}{c}22.3 \pm 0.2(4.33 \pm \\
0.01)\end{array}$ & $\begin{array}{c}21.8 \pm 0.3(1.17 \\
\pm 0.02)\end{array}$ & 327 & 359 & 161 \\
\hline
\end{tabular}

${ }^{a}$ Compounds are listed in order of elution, ${ }^{b}$ d.e. $=$ dried extract.

Previous research found in literature reported rosmarinic acid levels in Ocimum basilicum L. cultivars, varied from $0.06 \mathrm{mg} / \mathrm{g}$ to $12.7 \mathrm{mg} / \mathrm{g}$ on the dried matter, with caftaric acid levels ranging from $0.002 \mathrm{mg} / \mathrm{g}$ to $0.49 \mathrm{mg} / \mathrm{g}$ [25]. Our results highlighted an interesting composition of $O$. campechianum that could be suggested as an alternative for O. basilicum, with reference to the content of rosmarinic acid.

Ruiz-Vargas et al. (2020) reported the isolation from O. campechianum infusion of 5-demethyl nobiletin, 5-demethyl sinensetin, luteolin, methyl rosmarinate, and rosmarinic acid. Except the last compound the others have not been detected in our research [19].

\subsection{Antioxidant Activity}

All extracts exhibited a noteworthy antioxidant capacity in both performed tests (DPPH and ABTS). In particular, EO showed the highest radical scavenging activity in both assays (Table 3) with an $\mathrm{IC}_{50}$ of $7.7 \pm 0.1 \mu \mathrm{g} / \mathrm{mL}$ against $\mathrm{DPPH}$ and $3.18 \pm 0.29 \mu \mathrm{g} / \mathrm{mL}$ against ABTS, both close to the value obtained with the positive control (Trolox). This direct action of $\mathrm{EO}$ against the propagation of the prooxidative radical reaction could be due to the abundant presence of eugenol, although it should not be forgotten that the total antioxidant capacity of EO could also be the result of the complex interaction between the components in which synergistic or antagonistic actions intervene. In effect, the O. campechianum EO, even though it consists of about $44 \%$ eugenol, is also characterized by a good amount of cyclohexadiene-like components $(\sim 12 \% \beta$-elemene and $\delta$-elemene) that could work synergistically to offer high protection against oxidative processes [26]. The experimental results of the eugenol antiradical scavenger tests are further proof of the above, in fact they showed $\mathrm{IC}_{50}$ lower than EO and comparable to the positive control (Table 3), confirming previously data of literature [27]. Due to its antioxidant and anti-inflammatory effects, eugenol has been already studied for the treatment of irritant contact dermatitis [28], and also as components of active packaging to reduce the microbial decay and to preserve the antioxidant characteristics of table grapes [29], strawberries [30], and bayberries [31].

Table 3. DPPH and ABTS $\mathrm{IC}_{50}(\mu \mathrm{g} / \mathrm{mL})$ of $O$. campechianum extracts, EO, and main compounds.

\begin{tabular}{ccc}
\hline Extracts and Compounds & ${\text { DPPH } \text { IC }_{\mathbf{5 0}}}$ & ABTS IC $_{\mathbf{5 0}}$ \\
\hline O. campechianum $70 \%$ EtOH extract & $11.10 \pm 1.13$ & $8.58 \pm 0.53$ \\
O. campechianum MeOH extract & $52.15 \pm 2.72$ & $15.15 \pm 0.52$ \\
Rosmarinic acid & $4.31 \pm 0.34$ & $1.93 \pm 0.07$ \\
Trolox (positive control) & $3.66 \pm 0.29$ & $2.14 \pm 0.25$ \\
O. campechianum EO & $7.77 \pm 0.07$ & $3.18 \pm 0.29$ \\
Eugenol & $5.64 \pm 0.27$ & $8.58 \pm 0.53$ \\
\hline
\end{tabular}


As for the other extracts, the hydroalcoholic one exhibited a bioactivity close to the one of EO, while the methanolic displayed a weaker activity when compared to the previous. Both ethanolic and methanolic extract are rich in rosmarinic acid, showing $\mathrm{IC}_{50}$ values close to Trolox, confirming previously data of literature [32], but the ethanolic one showed a slightly higher content of the other identified phenolic acids and flavonoids (Table 2) than the methanolic extract. Probably, the reasons for the modest result of radical scavenger activity of the latter phytocomplex could also be attributed to this factor. However, the results confirmed very promising antioxidant properties for all extracts. The positive evaluation of the direct antioxidant activity through two techniques (DPPH and ABTS tests), the considerable presence of rosmarinic acid and eugenol (well known in the literature for their health potential), and the studies already underway to exploit the high antioxidant potential of the latter two molecules suggest that these results can be considered reliable to predict good future prospects for the use of O. campechianum, crude drug and extracts, in the health and wellness market.

\subsection{Antimicrobial Activity of O. campechianum}

The assay was performed on a 96-well plate in microplate reader.

The tests performed against the Gram-positive bacteria considered (Staphylococcus aureus, ATCC 6538) did not show any noteworthy activities for the extracts and rosmarinic acid, while eugenol, already well known in the literature for its antibacterial capacity [27], exhibited a MIC value under the $2000 \mu \mathrm{g} / \mathrm{mL}$ (Table 4). Regarding the Gram-negative bacteria, instead, $P$. syringae pv. syringae is the most polyphagous bacterium in the $P$. syringae complex that primarily affects woody and herbaceous host plants. The data obtained revealed noteworthy phytopatogenic activity of $O$. campechianum EO, and eugenol, against $P$. syringae pv. syringae, pointing out this extract as an interesting candidate for future deeper investigation for phytoiatric application. Eugenol is an active substance yet approved by European Parliament and Council in 2013 for the formulation of plant protection products [33]. On the strength of our results, the EO of O. campechianum could also become a promising active substance for plant protection as potential succedaneum of clove oil, already included in European Regulation 540/2011 [34] and with eugenol as main compound. These considerations may be of interest for both the development of a local economy and the international trade of this species. Moreover, previous literature was not reach of antimicrobial studies about $O$. campechianum extracts, and the few founded highlighted the antimicrobial activity of O. campechianum EO using different methods [18] or adopting a method that is not clearly decipherable and reproducible [35]. Therefore, these data could enrich the panorama of the antimicrobial activity of $O$. campechianum extracts.

Table 4. MICs of O. campechianum extracts, EO, and main compounds.

\begin{tabular}{ccc}
\hline Extracts and Compounds & $\begin{array}{c}\text { MIC }(\mu \mathrm{g} / \mathrm{mL}) \\
\text { Staphylococcus aureus } \\
\text { (ATCC 6538) }\end{array}$ & $\begin{array}{c}\text { MIC }(\mu \mathrm{g} / \mathrm{mL}) \\
\text { Pseudomonas syringae pv. } \\
\text { syringae (ATCC 19310) }\end{array}$ \\
\hline O. campechianum 70\% EtOH extract & $>2000$ & $>2000$ \\
O. campechianum MeOH extract & $>2000$ & $>2000$ \\
Rosmarinic acid & $>2000$ & $>2000$ \\
Cloramphenicol (positive control) & 10 & 2.5 \\
O. campechianum EO & $>2000$ & 250 \\
Eugenol & 1000 & 500 \\
\hline
\end{tabular}

Starting from literature data regarding the effect of $O$. campechianum EO against Candida spp., we investigated its potential alone and in combination with fluconazole against Candida clinical strains $[18,35]$. Due to the increasing levels of Candida spp. resistance to antifungal agents, the research of other remedies, more effective and safer than the current ones, is of great interest [36]. The synergistic effect of eugenol in combination with fluconazole was already described in literature [26]. Taking this fact into account and 
considering the composition of O. campechianum EO, this crude extract could be a new potential remedy against Candida spp. resistance.

The MIC and MFC results that gave the best FIC index data are reported in Table 5 . The MIC and MFC values for EO against all three strains were moderate. Even if no synergistic

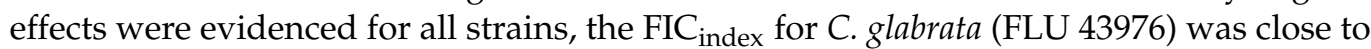
the value of synergism, with the EO MICs and MFCs 2-fold lower than those displayed by the alone EO and for fluconazole 32-fold lower than those of alone fluconazole. This result suggested that $O$. campechianum $\mathrm{EO}$ could be an interesting candidate to deeply investigate the synergism against fluconazole-resistant Candida spp.

Table 5. Synergistic effect of O. campechianum EO employing fluconazole as synthetic active drug against Candida spp.

\begin{tabular}{|c|c|c|c|c|c|c|}
\hline \multirow[b]{2}{*}{ C. albicans (AIDS6) } & \multirow{2}{*}{$\begin{array}{c}\text { FIC }_{\text {index }} \text { MIC } \\
\text { (EO + FLU) }\end{array}$} & \multirow{2}{*}{$\begin{array}{c}\text { FIC }_{\text {index }} \text { MFC } \\
\text { (EO + FLU) } \\
1.031 \\
(1563-4) *\end{array}$} & \multicolumn{2}{|c|}{$\begin{array}{c}\text { EO } \\
\text { MIC MFC }\end{array}$} & \multicolumn{2}{|c|}{$\begin{array}{c}\text { FLU } \\
\text { MIC MFC }\end{array}$} \\
\hline & & & 1563 & 1563 & 128 & 128 \\
\hline C. glabrata (FLU 43976) & $\begin{array}{c}0.562 \\
(781-8) *\end{array}$ & $\begin{array}{c}0.562 \\
(781-8) *\end{array}$ & 1563 & 1563 & 128 & 128 \\
\hline C. albicans (ATCC 24433) & $\begin{array}{c}1.004 \\
(3135-0.5) *\end{array}$ & $\begin{array}{c}1.004 \\
(3135-0.5) *\end{array}$ & 3135 & 3135 & 128 & 128 \\
\hline
\end{tabular}

FIC $_{\text {index }}$ : fractional inhibitory concentration index; FIC $_{\text {index }} \leq 0.5$ means the presence of synergistic effect; $0.5 \leq$ FIC $_{\text {index }} \leq 2$ means additive or indifferent effect; FIC $_{\text {index }}>2$ means antagonistic effect $[11,36] .{ }^{*}$ Concentration in $\mu \mathrm{g} / \mathrm{mL}$ of EO and FLU, respectively, corresponding to FIC index $_{\text {. MIC: }}$ Minimum Inhibitory Concentration ( $\mu \mathrm{g} / \mathrm{mL})$; MFC: Minimum Fungicidal Concentration $(\mu \mathrm{g} / \mathrm{mL})$. EO: O. campechianum EO; FLU: fluconazole.

\subsection{Cytotoxic Activity of O. campechianum}

$\mathrm{EO}, \mathrm{MeOH}$ and $70 \% \mathrm{EtOH}$ extracts of $\mathrm{O}$. campechianum were subjected to the 3(4,5-dimethylthiazol-2-yl)-2,5-diphenyl-2H-tetrazolium bromide (MTT) assay [37] for the evaluation of their cytotoxic effects on lung carcinoma (A549) during $24 \mathrm{~h}$ of exposure (Figure 1). The obtained data were compared with the values of the medium with dimethyl sulfoxide (DMSO) $0.1 \%$ (negative control), and doxorubicin was used as positive control (concentration range 0.1 to $20 \mu \mathrm{g} / \mathrm{mL}, \mathrm{IC}_{50}=2.92 \pm 0.12 \mu \mathrm{g} / \mathrm{mL}$ ).
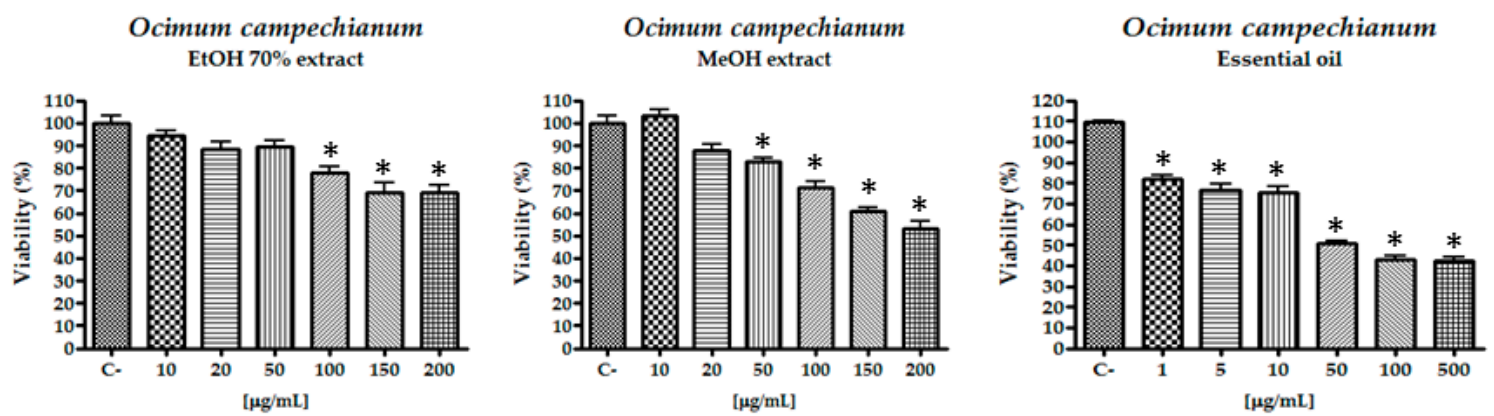

Figure 1. Cell viability of $O$. campechianum extracts and EO against A549 cell line. ${ }^{*} p<0.01$

A preliminary screening of the extracts revealed a negative outcome for the alcoholic ones, and a weak activity for the EO that exhibited an $\mathrm{IC}_{50}$ value of $71.89 \pm 3.84 \mu \mathrm{g} / \mathrm{mL}$. Rosmarinic acid was tested without obtaining any noteworthy results and eugenol did not reach an $\mathrm{IC}_{50}$ value at the highest concentration tested. As a matter of fact, Fangjun and Zhijia (2018) [38] showed that the latter molecule needs a concentration of at least $400 \mu \mathrm{M}$ to obtain a result after $24 \mathrm{~h}$ of exposure. Therefore, the activity of the EO could be possibly due to other molecules or to a synergistic activity inside the phytocomplex.

To complete the preliminary evaluation of the cytotoxic effect of the extracts and pure molecules, their effect was tested against a human keratinocyte cell line (HaCat). None 
of the extracts or pure molecule showed cytotoxicity against the HaCat cell line, giving indication of safe use of the extracts.

\subsection{Mutagenic Assay (Ames Test)}

To better define the awareness on the efficacy and the safe possible use of O. campechianum extracts and EO, Ames test was performed.

All tested concentrations showed a number of treated/control colonies ratio less than 2 , both in presence and in absence of $\mathrm{S} 9$ mix microsomal fraction (Table 6). Therefore, none of the texted extracts were considered potentially mutagenic. As regards the EO, a cytotoxic effect is noted at the highest concentrations. Our results pointed out the safety of O. campechianum extracts and EO with regard to genotoxicity [11].

Table 6. Treated/control (t/c) ratio of colony count in the Ames test.

\begin{tabular}{|c|c|c|c|c|c|c|c|c|c|c|c|c|}
\hline \multirow[b]{3}{*}{ Conc. $\%$ (mg/plate) } & \multicolumn{5}{|c|}{ O. Campechianum EO } & \multicolumn{3}{|c|}{$\begin{array}{l}\text { O. Campechianum } \\
70 \% \text { EtOH Extract }\end{array}$} & \multicolumn{4}{|c|}{$\begin{array}{c}\text { O. Campechianum } \mathrm{MeOH} \\
\text { Extract }\end{array}$} \\
\hline & \multicolumn{2}{|c|}{ TA98 (t/c) * } & \multicolumn{2}{|c|}{$\operatorname{TA100}(\mathrm{t} / \mathrm{c}) *$} & \multicolumn{2}{|c|}{ TA98 $(\mathrm{t} / \mathrm{c})^{*}$} & \multicolumn{2}{|c|}{$\operatorname{TA100}(t / c) *$} & \multicolumn{2}{|c|}{ TA98 (t/c) * } & \multicolumn{2}{|c|}{ TA100 (t/c) * } \\
\hline & $-\mathrm{S9}$ & +S9 & $-\mathrm{S} 9$ & +S9 & $-\mathrm{S9}$ & +S9 & $-S 9$ & +S9 & $-\mathrm{S} 9$ & +S9 & $-\mathrm{S9}$ & +S9 \\
\hline $5(0.25 \mathrm{mg} / \mathrm{plate})$ & 0.9 & 0.7 & 1.0 & 0.8 & 0.7 & 1.0 & 0.9 & 0.8 & 0.4 & 0.9 & 1.2 & 0.9 \\
\hline 10 (0.5 mg/plate) & 0.9 & 0.5 & 1.0 & 0.8 & 0.7 & 1.2 & 0.9 & 1.0 & 0.7 & 0.9 & 1.1 & 0.9 \\
\hline 20 (1 mg/plate) & 0.9 & 0.6 & 0.9 & 0.7 & 0.7 & 1.0 & 0.9 & 0.9 & 0.5 & 0.7 & 0.9 & 0.9 \\
\hline 50 (2.5 mg/plate) & 1.1 & 0.3 & 0.5 & 0.2 & 1.0 & 0.5 & 1.1 & 1.0 & 0.3 & 0.8 & 1.0 & 0.9 \\
\hline 100 (5 mg/plate) & 0.3 & 0.0 & 0.0 & 0.2 & 0.7 & 0.7 & 1.0 & 0.7 & 0.6 & 0.5 & 1.1 & 1.0 \\
\hline $\mathrm{C}+* *$ & 4.4 & 4.3 & 5.4 & 4.6 & 4.4 & 4.3 & 5.4 & 4.6 & 3.8 & 4.3 & 5.6 & 4.6 \\
\hline
\end{tabular}

${ }^{*} \mathrm{t} / \mathrm{c}$ means the ratio between the number of colonies of Salmonella strains grown in presence of EO and those of the negative control (DMSO) $.{ }^{* *} \mathrm{C}+$ : positive controls, that were: 2 -aminoanthracene $(2 \mu \mathrm{g} / \mathrm{plate})$ and 2-nitrofluorene $(2 \mu \mathrm{g} / \mathrm{plate})$ for TA98 with and without metabolic activator (S9 mix) respectively; 2-aminoanthracene ( $2 \mu \mathrm{g} / \mathrm{plate})$ and sodium azide ( $2 \mu \mathrm{g} / \mathrm{plate})$ for TA100, with and without metabolic activator (S9 mix) respectively.

\section{Materials and Methods}

\subsection{Plant Material}

The aerial parts of $O$. campechianum Mill. (stems, leaves and inflorescences; $20 \mathrm{Kg}$ ) were collected in January 2019, at early flowering stage at the CIPCA (Centre for Research, Postgraduate and Conservation of the Amazon, Santa Clara, Ecuador) of the Universidad Estatal Amazónica (UEA) $\left(01^{\circ} 14^{\prime} 13^{\prime \prime}\right.$ S, $077^{\circ} 53^{\prime} 25^{\prime \prime}$ W, $\left.570 \mathrm{~m}\right)$, from a wild population in the Amazonian region of Napo (Arosemena Tola canton), Ecuador. The authentication was performed at the Amazon State University (UEA), using as reference a specimen previously deposited in the Herbarium ECUAMZ (voucher specimen: Radice 18070D).

\subsection{Preparation of Extracts}

The EO was obtained by hydrodistillation of fresh aerial parts ( $5 \mathrm{Kg}$ with $10 \mathrm{~L}$ of water) for $3 \mathrm{~h}$ in a stainless-steel distiller equipped with a Clevenger apparatus, performing three distinct distillations. The EO content was calculated on a moisture-free basis as average. The EO was dried over anhydrous sodium sulfate and stored in sealed amber vials at $4{ }^{\circ} \mathrm{C}$.

Before proceeding with the alcoholic extraction, the dried aerial parts of $O$. campechianum $(350 \mathrm{~g}$ ) were milled through a $2 \mathrm{~mm}$ sieving ring of a Variable Speed Rotor Mill (Fritsch, Idar- Oberstein, Germany). Afterwards, $50 \mathrm{~g}$ of powdered crude drug was added to $500 \mathrm{~mL}$ of methanol (Sigma-Aldrich, Milano, Italy), while another $50 \mathrm{~g}$ to $350 \mathrm{~mL}$ of absolute ethanol (Sigma-Aldrich, Milano, Italy) and $150 \mathrm{~mL}$ of distilled water to obtain a $70 \%$ ethanolic solution. The extraction was performed by means of an ultrasonic bath (Branson Bransonic CPXH Digital Bath 3800F, Emerson, St. Louis, MO, USA) for $30 \mathrm{~min}$ at a temperature of $30^{\circ} \mathrm{C}$. The extracts were filtered and the methanolic solution were evaporated to dryness with a rotary evaporator (RV 10 digital, IKA ${ }^{\circledR}$-Werke GmbH \& CO. KG, Staufen im Breisgau, Germany), while the ethanolic one was evaporated to dryness with a rotary evaporator and then lyophilized to eliminate residual water. All the extractions were 
performed in triplicate and dried extracts stored at $-20^{\circ} \mathrm{C}$. The EO content was calculated on a moisture-free basis as average.

\subsection{Gas Chromatography Coupled to Mass Spectrometric and Flame Ionization Analyses}

The analysis method and composition of EO was previously described by Scalvenzi et al. (2019) [10].

\subsection{HPLC-DAD-MS Analysis}

The analyses were performed using a JASCO modular HPLC system (Tokyo, Japan, model PU 2089) coupled to a diode array apparatus (MD 2010 Plus) and a FinniganMAT LCQ (ThermoQuest Corp./FinniganMAT; San Jose, CA, USA) mass spectrometer module linked to an injection valve with a $20 \mu \mathrm{L}$ sampler loop. The column used was a Kinetex-C18 $(15 \times 0.46 \mathrm{~cm}$, i.d., $5 \mu \mathrm{m}, 100 \AA$, Phenomenex $)$ at a flow rate of $0.7 \mathrm{~mL} / \mathrm{min}$ and at a temperature of $30^{\circ} \mathrm{C}$. The mobile phase consisted of binary solvent system of water/formic acid 99/1 (solvent A) and methanol (solvent B). The gradient system adopted was: starting point at 95:5 $v / v(\mathrm{~A} / \mathrm{B})$, gradual changing to $70: 30 \mathrm{v} / \mathrm{v}$ in $50 \mathrm{~min}$, isocratic condition up to $65 \mathrm{~min}$, back to starting point at $70 \mathrm{~min}$, re-equilibration of the system up to $85 \mathrm{~min}$. Injection volume was $40 \mu \mathrm{L}$. The chromatograms were observed at $355 \mathrm{~nm}$ [24].

The mass experiments were performed on a FinniganMAT LCQ (ThermoQuest Corp./FinniganMAT; San Jose, CA, USA) mass spectrometer module, equipped with an ion trap mass analyzer and an ESI ion source electrospray, in negative ion mode. For ESI-MS and $\mathrm{MS}^{2}$ experiments, the parameters were set as follows; the capillary voltage was $3.5 \mathrm{kV}$, the nebulizer $\left(\mathrm{N}_{2}\right)$ pressure was $20 \mathrm{psi}$, the capillary temperature was $300^{\circ} \mathrm{C}$, the auxiliary gas $\left(\mathrm{N}_{2}\right)$ flow was $9 \mathrm{~L} / \mathrm{min}$, and the skimmer voltage was $40 \mathrm{~V}$. The mass spectrometer was operated in the negative ion mode in the $\mathrm{m} / \mathrm{z}$ range 100-1500. Standard commercial molecules of quercetin $3-O-\beta$-rutinoside (rutin), caftaric, chlorogenic and rosmarinic acids were used to confirm the experimental data and to quantify these molecules in the extracts through the construction of calibration curves with solutions of concentrations from 1 to $50 \mu \mathrm{g} / \mathrm{mL}$ for rutin, 1 to $50 \mu \mathrm{g} / \mathrm{mL}$ for caftaric acid, 1 to $50 \mu \mathrm{g} / \mathrm{mL}$ for chlorogenic acid, and 10-350 $\mu \mathrm{g} / \mathrm{mL}$ for rosmarinic acid. All standards were purchased by Extrasynthese (Cedex, France). The two dried extracts of O. campechianum were, respectively, solubilized in hydroalcoholic solution (ethanol $70 \%$ ) at concentration of $4.0 \mathrm{mg} / \mathrm{mL}$ and in methanol at concentration of $2.5 \mathrm{mg} / \mathrm{mL}$.

\subsection{DPPH Scavenging Activity}

The DPPH assay was performed following the method by Cheng et al. (2006) [39]: briefly, the DPPH solution was placed on a 96-well plate containing different concentration of extract or pure compounds for $30 \mathrm{~min}$ in the dark at room temperature, then the microplates were analyzed with a microplate reader $(680 \mathrm{XR}$, Bio Rad, Laboratories, Inc., Hercules, CA, USA) and the absorbance was read in triplicate against a blank at $515 \mathrm{~nm}$. The DPPH inhibition in percent was determined by the following formula: $\mathrm{IDPPH} \%=[1-(\mathrm{A} 1 / \mathrm{A} 2)] \times 100$, where A1 was the DPPH absorbance with the extracts and A2 without extracts. Eight different concentrations (range: $20-0.16 \mu \mathrm{g} / \mathrm{mL}$ ) of Trolox were prepared and used as positive control. The activity of the extracts was expressed as $\mathrm{IC}_{50}$, concentration providing $50 \%$ inhibition of the radical. All experiments were performed in triplicate.

\subsection{ABTS Scavenging Activity}

The ABTS scavenging activity was evaluated using the method of Horszwald and Andlauer (2011) [40]. EO, alcoholic extracts and pure molecules (rosmarinic acid, eugenol, and Trolox) were tested in a range of concentrations, respectively, $37.00-0.58 \mu \mathrm{g} / \mathrm{mL}$, $133.33-2.08 \mu \mathrm{g} / \mathrm{mL}$, and $13.33-0.21 \mu \mathrm{g} / \mathrm{mL}$. Aqueous solution $(7 \mathrm{mmol} / \mathrm{L})$ of ABTS $(10 \mathrm{~mL})$ and $51.4 \mathrm{mmol} / \mathrm{L}$ aqueous solution of $\mathrm{K}_{2} \mathrm{~S}_{2} \mathrm{O}_{4}(0.5 \mathrm{~mL})$ were mixed to obtain a radical cation solution that has been adjusted spectrophotometrically to $0.7 \pm 0.05$ at $734 \mathrm{~nm}$. After 6 min 
of incubation in the dark at room temperature, microplates were analyzed with a microplate reader (680XR, Bio Rad, Laboratories, Inc., Hercules, CA, USA), and the absorbance was read at $734 \mathrm{~nm}$ in triplicate and against a blank. Antioxidant activity of the samples was expressed as $\mathrm{IC}_{50}$, the concentration providing 50\% radical inhibition. All experiments were assessed in triplicate and values were reported as mean \pm standard deviation.

\subsection{Antibacterial Activity}

The antibacterial activity has been evaluated against phytopathogenic and human pathogenic bacteria to preliminarily verify phytoiatric and health properties. Pseudomonas syringae pv. syringae ATCC 19310 and Staphylococcus aureus ATCC 6538 were used to determine MIC (Minimum Inhibitory Concentration) through microdilution method using 96-well microtiter plates [41]. Bacterial cultures were incubated overnight at $26^{\circ} \mathrm{C}$ and $37^{\circ} \mathrm{C}$, respectively, in Tryptic Soy Broth (OXOID Ltd., Hampshire, UK). One hundred $\mu \mathrm{L}$ of sterile medium were used together with $100 \mu \mathrm{L}$ of sample to perform serial dilutions of extracts, EO, rosmarinic acid and eugenol, previously dissolved in ethanol $(50 \mathrm{mg} / \mathrm{mL}$ of stock solution), into all micro-wells.

One-hundred microliters of bacterial culture standardized to $2 \times 10^{7} \mathrm{CFU} / \mathrm{mL}$ was added to the wells and incubated at $37{ }^{\circ} \mathrm{C}$ for $6 \mathrm{~h}$ and at $26^{\circ} \mathrm{C}$ for $24 \mathrm{~h}$, for human and phytopathogens, respectively. After the incubation period, $40 \mu \mathrm{L}$ of water solution (20 mg/mL) of 2,3,5-triphenyl-tetrazolium chloride (Sigma-Aldrich, St. Louis, MO, USA) was added to each well and then incubated for $30 \mathrm{~min}$ : microbial growth was evaluated by microplate reader (680XR, Bio Rad, Laboratories, Inc., Hercules, CA, USA) at $415 \mathrm{~nm}$. Chloramphenicol (concentration range $20-0.32 \mu \mathrm{g} / \mathrm{mL}$ ) was used as a positive control. All determinations were made in triplicate.

\subsection{Antimicrobial Activity against Candida spp. and Synergy Test}

Antimicrobial and synergy tests were performed against three Candida spp. strains: Candida albicans (AIDS6; fluconazole resistant clinical strain isolated from a HIV patient), Candida glabrata (FLU 43976; resistant to fluconazole), and Candida albicans (ATCC 24433; from American Type Culture Collections; sensitive to fluconazole). The Minimum Inhibitory Concentration (MIC) and Minimum Fungicidal Concentration (MFC) of $O$. campechianum EO and fluconazole (positive control) were determined through microdilution method using 96-well microtiter plates [41], properly modified according our previous research [11]. Synergistic evidence of anti-Candida activity was checked through checkerboard test using EO and fluconazole at the same experimental conditions employed for MIC and MFC determination, as previously described. The synergistic activity was expressed as fractional inhibitory concentration $\left(\mathrm{FIC}_{\text {index }}\right)$ and was calculated as follows,

$$
\mathrm{FIC}_{\text {index }}=\mathrm{FIC}_{\mathrm{EO}}+\mathrm{FIC}_{\text {fluconazole }}
$$

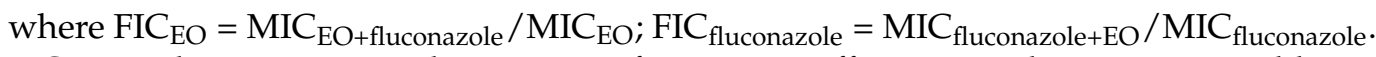
$\mathrm{FIC}_{\text {index }}$ values $\leq 0.5$ mean the presence of synergistic effect, $0.5<$ values $\leq 2$ mean additive or indifferent effect, values $>2$ mean antagonistic effect [36].

\subsubsection{Cell Lines and Culture Conditions}

Adenocarcinomic human alveolar basal epithelial cells (A549) and human keratinocytes (HaCat) were purchased by Istituto Zooprofilattico Sperimentale della Lombardia e dell'EmiliaRomagna, Brescia, Italy, and maintained, respectively, in Ham's F12 medium and DMEM containing $4.5 \mathrm{~g} / \mathrm{L}$ and $1 \mathrm{~g} / \mathrm{L}$ glucose. The cell lines were grown in $75 \mathrm{~cm}^{2}$ flasks and cultured in medium supplemented with $10 \%$ fetal bovine serum (FBS), $100 \mathrm{U} / \mathrm{mL}$ penicillin/streptomycin, and $2 \mathrm{mM}$ L-glutamine in a humidified $5 \% \mathrm{CO}_{2}-95 \%$ air atmosphere at $37^{\circ} \mathrm{C}$ until $80 \%$ confluence. 


\subsubsection{Cell Viability Assay}

Cell viability was determined by MTT colorimetric assay [24] as reflected by the activity of succinate dehydrogenase. Briefly, cells were seeded at the density of $2 \times 10^{4}$ cells/well on a 96-well plate. After $24 \mathrm{~h}$, cells were exposed to different concentrations of O. campechianum EO (1-500 $\mu \mathrm{g} / \mathrm{mL})$, O. campechianum 70\% ethanolic extract $(10-200 \mu \mathrm{g} / \mathrm{mL}), O$. campechianum methanolic extract $(10-200 \mu \mathrm{g} / \mathrm{mL})$, eugenol and rosmarinic acid $(1-100 \mu \mathrm{M})$ in a final volume of $200 \mu \mathrm{L}$ of culture medium. Control culture was exposed to only vehicle (medium containing 2\% FBS). After $24 \mathrm{~h}$ of incubation, $20 \mu \mathrm{L}$ of MTT ( $5 \mathrm{mg} / \mathrm{mL}$ in phosphate-buffered saline, PBS) was added in each well and the plates were incubated for $4 \mathrm{~h}$ at $37^{\circ} \mathrm{C}$. The medium was removed and replaced with $100 \mu \mathrm{L}$ DMSO to dissolve the formazan crystals. The extent of MTT reduction was measured spectrophotometrically at $570 \mathrm{~nm}$ using a microplate reader (680XR, Bio Rad, Laboratories, Inc., Hercules, CA, USA).

\subsection{Mutagenic Assay}

Mutagenicity assay was performed following the plate incorporation method with the histidine-requiring Salmonella typhimurium mutant TA98 and TA100 strains purchased by Molecular Toxicology Inc. (Boone, NC, USA; moltox.com). All strains (100 $\mu \mathrm{L}$ per plate of fresh overnight cultures) were checked with and without the addition of $0.5 \mathrm{~mL}$ of a $5 \% \mathrm{~S} 9$ exogenous metabolic activator (S9 mix). The lyophilized post-mitochondrial supernatant S9 mix (Aroclor 1254-induced, Sprague-Dawley male rat liver in $0.154 \mathrm{M} \mathrm{KCl}$ solution), commonly used for the activation of pro-mutagens to mutagenic metabolites (Molecular Toxicology, Inc., Boone, NC, USA) was stored at $-80^{\circ} \mathrm{C}$ before use. The concentration tested for all the samples were $5,10,20,50$, and $100 \mu \mathrm{L} /$ plate of a stock solution $50 \mathrm{mg} / \mathrm{mL}$. An amount of $0.5 \mathrm{~mL}$ of phosphate buffer or S9 mix for assays with metabolic activation was added to $2 \mathrm{~mL}$ molten top agar $(0.6 \%$ agar, $0.6 \% \mathrm{NaCl}, 0.5 \mathrm{mM}$ L-histidine/biotin solution) at $46^{\circ} \mathrm{C}$, together with $0.1 \mathrm{~mL}$ of each sample solution at different concentrations, and $0.1 \mathrm{~mL}$ of fully-grown culture of the appropriate tester strain. The ingredients were thoroughly mixed and poured onto minimal glucose agar plates $(1.5 \%$ agar in $2 \%$ VogelBonner medium $\mathrm{E}$ with $5 \%$ glucose solution). DMSO was used as a negative control (100 $\mu \mathrm{L} /$ plate). Positive controls were prepared as follows: 2-aminoanthracene ( $2 \mu \mathrm{g} / \mathrm{plate})$ for both strains with metabolic activation a 2-nitrofluorene $(2 \mu \mathrm{g} /$ plate $)$ and sodium azide $(2 \mu \mathrm{g} /$ plate) for TA98 and TA100 without metabolic activator, respectively. The plates were incubated at $37^{\circ} \mathrm{C}$ for $72 \mathrm{~h}$ and then the his + revertants were checked and counted using a Colony Counter 560 Suntex (Antibioticos, Italy). A sample was considered mutagenic when the observed number of colonies was at least twofold over the spontaneous level of revertants [11]. All determinations were made in triplicate.

\subsection{Statistical Analysis}

Data are reported as mean \pm standard error of the mean, and " $\mathrm{n}$ " was the number of independent experiments performed in triplicate. The statistical analysis for cell viability was calculated using one-way analysis of variance (ANOVA), followed by Dunnett's Test. The results were considered significant with $p<0.01$ compared to untreated cells.

\section{Conclusions}

The present work provides for the first time the chemical quantification of secondary metabolites in alcoholic extracts of $O$. campechianum, enhancing the knowledge on the phytochemicals produced by this species, currently known only for its EO.

On the basis of the in vitro results of this research, the crude drug and alcoholic extracts of $O$. campechianum could be proposed as safe alternative to $O$. basilicum, in consideration of the content of rosmarinic acid. On the other hand regarding the antimicrobial effect of $O$. campechianum $\mathrm{EO}$, it could be suggested as a succedaneum of clove oil with a projection in human health and phytoiatric uses.

In the final analysis, this species represents an interesting sustainable resource for future development of local economy and for trade at international level. 
Author Contributions: The contributions of authors are as follow: Conceptualization, M.T. and A.G. (Alessandra Guerrini); Data curation, M.T., A.G. (Alessandro Grandini), and I.M.; Formal analysis, M.T., M.P.E.G., A.G. (Alessandro Grandini), I.M., M.R. and A.G. (Alessandra Guerrini); Funding acquisition, A.G. (Alessandro Grandini) and A.G. (Alessandra Guerrini); Investigation, M.T. and A.G. (Alessandra Guerrini); Methodology, M.T. and L.A.; Resources, M.P.E.G. and M.R.; Supervision, M.T., L.A. and A.G. (Alessandra Guerrini); Writing—original draft,. A.G. (Alessandra Guerrini). All authors have read and agreed to the published version of the manuscript.

Funding: This research was funded by FAR2018 (Guerrini) grant of the University of Ferrara, "Fondazione Dott. Carlo Fornasini" 2015 (Poggio Renatico, Ferrara) Grandini grant, FFABR 2017MIUR (Guerrini).

Data Availability Statement: Data is contained within the article.

Sample Availability: Samples of extracts used in the study are available from the authors.

Acknowledgments: The authors are grateful to David Neill for the contribution in botanical authentication of O. campechianum species.

Conflicts of Interest: The authors declare no conflict of interest.

\section{References}

1. Bailon-Moscoso, N.; Romero-Benavides, J.C.; Tinitana-Imaicela, F.; Ostrosky-Wegman, P. Medicinal plants of Ecuador: A review of plants with anticancer potential and their chemical composition. Med. Chem. Res. 2015, 24, 2283-2296. [CrossRef]

2. Worldatlas. 17 Most Ecologically Diverse Countries on Earth. Available online: http://www.worldatlas.com/articles/ ecologically-megadiverse-countries-of-the-world.html (accessed on 2 December 2020).

3. Guerrini, A.; Sacchetti, G.; Grandini, A.; Spagnoletti, A.; Asanza, M.; Scalvenzi, L. Cytotoxic Effect and TLC BioautographyGuided Approach to Detect Health Properties of Amazonian Hedyosmum sprucei Essential Oil. Evid. Based Complement. Alternat. Med. 2016, 2016, 1638342. [CrossRef]

4. Lubbe, A.; Verpoorte, R. Cultivation of medicinal and aromatic plants for specialty industrial materials. Ind. Crops Prod. 2011, 34, 785-801. [CrossRef]

5. Maia, J.G.S.; Andrade, E.H.A. Database of the Amazon aromatic plants and their essential oils. Quím. Nova 2009, 32, 595-622. [CrossRef]

6. Sacchetti, G.; Guerrini, A.; Noriega, P.; Bianchi, A.; Bruni, R. Essential oil of wild Ocotea quixos (Lam.) Kosterm. (Lauraceae) leaves from Amazonian Ecuador. Flavour Frag. J. 2006, 21, 674-676. [CrossRef]

7. Malagón, O.; Ramírez, J.; Andrade, J.M.; Morocho, V.; Armijos, C.; Gilardoni, G. Phytochemistry and ethnopharmacology of the Ecuadorian flora. A Review. Nat. Prod. Commun. 2016, 11, 297-314. [CrossRef]

8. Batish, D.R.; Singh, H.P.; Kohli, R.K.; Kaur, S. Eucalyptus essential oil as a natural pesticide. For. Ecol. Manag. 2008, 256, 2166-2174. [CrossRef]

9. Caballero-Serrano, V.; McLaren, B.; Carrasco, J.C.; Alday, J.G.; Fiallos, L.; Amigo, J.; Onaindia, M. Traditional ecological knowledge and medicinal plant diversity in Ecuadorian Amazon home garden. Glob. Ecol. Conserv. 2019, 17, e00524. [CrossRef]

10. Scalvenzi, L.; Radice, M.; Toma, L.; Severini, F.; Boccolini, D.; Bella, A.; Guerrini, A.; Tacchini, M.; Sacchetti, G.; Chiurato, M.; et al Larvicidal activity of Ocimum campechianum, Ocotea quixos and Piper aduncum essential oils against Aedes aegypti. Parasite 2019, 26, 23. [CrossRef]

11. Ballesteros, J.L.; Tacchini, M.; Spagnoletti, A.; Grandini, A.; Paganetto, G.; Neri, L.M.; Marengo, A.; Angiolella, L.; Guerrini, A.; Sacchetti, G. Rediscovering Medicinal Amazonian Aromatic Plants: Piper carpunya (Piperaceae) Essential Oil as Paradigmatic Study. Evid. Based Complement. Alternat. Med. 2019, 2019, 6194640. [CrossRef]

12. Guerrini, A.; Rossi, D.; Grandini, A.; Scalvenzi, L.; Rivera, P.F.N.; Andreotti, E.; Sacchetti, G. Biological and chemo-diverse characterization of Amazonian (Ecuador) Citrus petitgrains. J. Appl. Bot. Food Qual. 2014, 87, 108-116.

13. Rossi, D.; Guerrini, A.; Maietti, S.; Bruni, R.; Paganetto, G.; Poli, F.; Sacchetti, G. Chemical fingerprinting and bioactivity of Amazonian Ecuador Croton lechleri Müll. Arg. (Euphorbiaceae) stem bark essential oil: A new functional food ingredient? Food Chem. 2011, 126, 837-848. [CrossRef]

14. Scalvenzi, L.; Grandini, A.; Spagnoletti, A.; Tacchini, M.; Neill, D.; Ballesteros, J.L.; Sacchetti, G.; Guerrini, A. Myrcia splendens (Sw.) DC. (syn. M. fallax (Rich.) DC.) (Myrtaceace) essential oil from Amazonian Ecuador: A chemical characterization and bioactive profile. Molecules 2017, 22, 1163. [CrossRef]

15. Jaramillo, B.; Duarte, E.; Delgado, W. Bioactivity of essential oil from Ocimum micranthum Willd, collected from Bolivar department, Colombia. Rev. Cuba. Plantas Med. 2014, 19, 185-196.

16. Salles Trevisan, M.T.; de Vasconelos Silva, M.G.; Pfundstein, B.; Spiegelhalder, B.; Wyn Owen, R. Characterization of the Volatile Pattern and Antioxidant Capacity of Essential Oils from Different Species of the Genus Ocimum. J. Agric. Food Chem. 2006, 54, 4378-4382. [CrossRef] 
17. De Vasconcelos Silva, M.G.; Abreu Matos, F.J.; Lacerda Machado, M.I.; de Oliveira Silva, F. Essential Oil Composition of the Leaves of Ocimum micranthum Willd. J. Essent. Oil Res. 2004, 16, 189-190. [CrossRef]

18. Sacchetti, G.; Medici, A.; Maietti, S.; Radice, M.; Muzzoli, M.; Manfredini, S.; Braccioli, E.; Bruni, A. Composition and Functional Properties of the Essential Oil of Amazonian Basil, Ocimum micranthum Willd., Labiatae in Comparison with Commercial Essential Oils. J. Agric. Food. Chem. 2004, 52, 3486-3491. [CrossRef]

19. Ruiz-Vargas, J.A.; Morales-Ferra, D.L.; Ramirez-Avila, G.; Zamilpa, A.; Negrete-Leon, E.; Acevedo-Fernandez, J.J.; Pena-Rodriguez, L.M. $\alpha$ - Glucosidase inhibitory activity and in vivo antihyperglycemic effect of secondary metabolites from the leaf infusion of Ocimum campechianum Mill. J. Ethnopharm. 2019, 243, 112081. [CrossRef]

20. Gry, J.; Black, L.; Damsted Eriksen, F.; Pilegaard, K.; Plumb, J.; Rhodes, M.; Sheehan, D.; Kiely, M.; Kroon, P.A. EuroFIR-BASIS-a combined composition and biological activity database for bioactive compounds in plant-based foods. Trends Food. Sci. Tech. 2007, 18, 434-444. [CrossRef]

21. Adams, R.P. Identification of Essential Oil Components by Gas Chromatography/Mass Spectrometry, 4th ed.; Allured Busines Media: Carol Stream, IL, USA, 2007.

22. Figueiredo, P.L.B.; Silva, S.G.; Nascimento, L.D.; Ramos, A.R.; Setzer, W.N.; da Silva, J.K.R.; Andrade, E.H.A. Seasonal Study of Methyleugenol Chemotype of Ocimum campechianum Essential Oil and Its Fungicidal and Antioxidant Activities. Nat. Prod. Commun. 2018, 13, 1055-1058. [CrossRef]

23. Villalva, M.; Jaime, L.; Aguado, E.; Nieto, J.A.; Reglero, G.; Santoyo, S. Anti-Inflammatory and Antioxidant Activities from the Basolateral Fraction of Caco-2 Cells Exposed to a Rosmarinic Acid Enriched Extract. J. Agric. Food Chem. 2018, 66, 1167-1174. [CrossRef]

24. Vinueza, D.; Yanza, K.; Tacchini, M.; Grandini, A.; Sacchetti, G.; Chiurato, M.; Guerrini, A. Flavonoids in Ecuadorian Oreocallis grandiflora (Lam.) R. Br.: Perspectives of use of this species as a food supplement. Evid. Based Complement. Alternat. Med. 2018, 2018, 1353129. [CrossRef]

25. Kwee, E.M.; Niemeyer, E.D. Variations in phenolic composition and antioxidant properties among 15 basil (Ocimum basilicum L.) cultivars. Food Chem. 2011, 128, 1044-1050. [CrossRef]

26. Amorati, R.; Foti, M.C.; Valgimigli, L. Antioxidant Activity of Essential Oils. J. Agric. Food Chem. 2013, 61, 10835-10847. [CrossRef]

27. Kamatou, G.P.; Vermaak, I.; Viljoen, A.M. Eugenol-from the remote Maluku Islands to the international market place: A review of a remarkable and versatile molecule. Molecules 2012, 17, 6953-6981. [CrossRef]

28. De Araújo Lopes, A.; da Fonseca, F.N.; Rocha, T.M.; de Freitas, L.B.; Oliveira Araújo, E.V.; Tenazoa Wong, D.V.; Pereira Lima Júnior, R.C.; Almeida Moreira, L.K. Eugenol as a promising molecule for the treatment of dermatitis: Antioxidant and anti-inflammatory activities and its nanoformulation. Oxid. Med. Cell Longev. 2018, 2018, 8194849. [CrossRef]

29. Valero, D.; Valverde, J.M.; Martinez-Romero, D.; Guillen, F.; Castillo, S.; Serrano, M. The combination of modified atmosphere ackaging with eugenol or thymol to maintain quality, safety and functional properties of table grapes. Postharvest Biol. Technol. 2006, 41, 317-327. [CrossRef]

30. Wang, C.Y.; Wang, S.Y.; Yin, J.-J.; Parry, J.; Yu, L.L. Enhancing antioxidant, antiproliferation, and free radical scavenging activities in strawberries with essential oils. J. Agric. Food Chem. 2007, 55, 6527-6532. [CrossRef]

31. Jin, P.; Wu, X.; Xu, F.; Wang, X.; Wang, J.; Zheng, Y. Enhancing antioxidant capacity and reducing decay of Chinese bayberries by essential oils. J. Agric. Food Chem. 2012, 60, 3769-3775. [CrossRef]

32. Nadeem, M.; Imran, M.; Gondal, T.A.; Imran, A.; Shahbaz, M.; Amir, R.; Sajid, M.W.; Qaisrani, T.; Atif, M.; Hussain, G.; et al. Therapeutic potential of rosmarinic acid: A comprehensive review. Appl. Sci. 2019, 9, 3139. [CrossRef]

33. Commission Implementing Regulation (EU). Commission Implementing Regulation (EU) No 546/2013 Approving the Active Substance Eugenol, in Accordance with Regulation (EC) No 1107/2009 of the European Parliament and of the Council Concerning the Placing of Plant Protection Products on the Market, and Amending the Annex to Commission Implementing Regulation (EU) No 540/2011. OJ L 2013, 163, 17-20.

34. Commission Implementing Regulation (EU). Commission Implementing Regulation (EU) No 540/2011implementing Regulation (EC) No 1107/2009 of the European Parliament and of the Council as Regards the List of Approved Active Substances Text with EEA Relevance. OJ L 2011, 153, 1-186.

35. Caamal-Herrera, I.O.; Carrillo-Cocom, L.M.; Escalante-Réndiz, D.Y.; Aráiz-Hernández, D.; Azamar-Barrios, J.A. Antimicrobial and antiproliferative activity of essential oil, aqueous and ethanolic extracts of Ocimum micranthum Willd leaves. BMC Complement. Altern. Med. 2018, 18, 55. [CrossRef]

36. Zaidi, K.U.; Shah, F.; Parmar, R.; Thawani, V. Anticandidal synergistic activity of Ocimum sanctum and fluconazole of azole resistance strains of clinical isolates. J. Mycol. Med. 2018, 28, 289-293. [CrossRef]

37. Mosmann, T. Rapid colorimetric assay for cellular growth and survival: Application to proliferation and cytotoxicity assays. J. Immunol. Methods 1983, 65, 55-63. [CrossRef]

38. Fangjun, L.; Zhijia, Y. Tumor suppressive roles of eugenol in human lung cancer cells. Thorac. Cancer. 2018, 9, 25-29. [CrossRef]

39. Cheng, Z.; Moore, J.; Yu, L.L. High-Throughput Relative DPPH Radical Scavenging Capacity Assay. J. Agric. Food Chem. 2006, 54, 7429-7436. [CrossRef]

40. Horszwald, A.; Andlauer, W. Characterisation of bioactive compounds in berry juices by traditional photometric and modern microplate methods. J. Berry Res 2011, 1, 189-199. [CrossRef]

41. CLSI (Clinical Laboratory Standards Institute). Methods for Dilution Antimicrobial Susceptibility Tests for Bacteria that Grow Aerobically, 9th ed.; Approved Standard M07-A10; CLSI: Wayne, PA, USA, 2015. 